\section{Sustaining and Strengthening Indonesia Art and Culture}

\author{
A.M. Hermien Kusmayati ${ }^{1}$ \\ Jurusan Tari, Fakultas Seni Pertunjukan, Institut Seni Indonesia Yogyakarta
}

\begin{abstract}
This study aims to analyze the background and sustainability of plurality or diversity of Indonesian art and culture in the form of implementation as a revitalization of traditional performing arts. Qualitative research with an ethnographic approach and an emic and ethical point of view are employed to observe it. The richness of art - both material and non-material with its various aspects are created through struggles against nature, space, and time which are not always easy to address. The cone-shaped cultural wealth as an art is created from the depths of consciousness, understanding, and insight which are not simple but bearing various symbols. The use of symbols in the form of art lengthens its roots from one generation to the next as a representation of the clarity and wisdom of the crystallization of the intelligence of feelings and thoughts. Informal and non-formal educations are efforts which can be done by the present generation to confirm its sustainability. In the vastness of a very open global era, as intercultural interactions intensify, a strong and resilient culture is needed. As something inherited, the future sustainability lies in the hands of the generation, i.e. the society of the recipients in the present and the future.
\end{abstract}

Keywords: Indonesian art; traditional dance; batik; mamaca

\begin{abstract}
Abstrak
Keberlanjutan dan Penguatan Seni-Budaya. Penelitian ini bertujuan untuk menganalisis latar belakang dan keberlanjutan pluralitas atau keberagaman seni budaya Indonesia dalam wujud pelaksanaan sebagai suatu revitalisasi seni pertunjukan tradisi. Penelitian kualitatif dengan pendekatan etnografis dan sudut pandang emik serta etik ditempatkan untuk mencermatinya. Kekayaan seni - budaya baik bendawi maupun non bendawi dengan berbagai aspeknya diciptakan melalui pergulatan terhadap alam, ruang, dan waktu yang tidak selalu mudah disikapi. Kekayaan budaya yang mengerucut sebagai seni yang diciptakan dari kedalaman kesadaran, pemahaman, serta penghayatan yang tidak sederhana bermuatan berbagai simbol. Penggunaan simbol-simbol dalam wujud seni, memanjangkan akarnya dari satu generasi ke generasi berikutnya sebagai representasi kejernihan dan kearifan dari kristalisasi kecerdasan perasaan dan pikiran. Melalui dan di dalam pendidikan baik formal maupun non formal adalah upaya yang dapat dilakukan oleh generasi sekarang untuk meneguhkan keberlanjutannya. Di keluasan era global yang sangat terbuka, ketika interaksi kebudayaan antarbangsa semakin intensif, sungguh diperlukan ketahanan budaya yang sangat kuat dan tangguh. Sebagai sesuatu yang diwariskan, maka kelanjutannya di masa depan berada di tangan generasi pewarisnya, yaitu masyarakat penerimanya pada saat sekarang maupun yang akan datang.

Kata kunci: kesenian Indonesia; tari tradisi; batik; mamaca
\end{abstract}

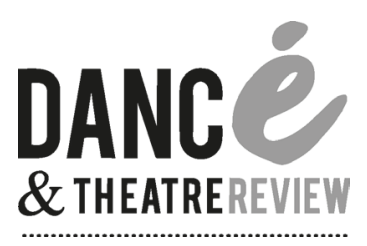

jurnal tari, teater, dan wayang volume 1 number 1, May 2018 page $43-49$ 


\section{Introduction}

In the long journey of complex human life, art is part of its supporting component. The work of humans imitating something beautiful and manifesting in the title of art is an important component which contributes to human life as individuals and groups. Different appearance from each other and potentially becoming unique because it was originally presented for the fulfillment of a need. Its presence delivers a certain power with its own benchmarks which are absorbed by the senses and capable of vibrating them (Marianto, 2016: 2-3).

Jakob Sumardjo (2006: 91) and other experts claim that art is present or manifested by sensual experience and perception and is able to generate intellectual awareness and feelings. Hearing and vision are sensual and sensitive dual-senses which are often needed to display and pervade the artwork. However, in the development of particular art, some of the artworks presented are also intended to be infused through touching and rubbing sensitivity. Audience is allowed to touch and rub the works which normally can only be enjoyed visually. The absorbing power depends on the vacant of experience and sensitivity of the individual senses when facing it (Junaedi, 2016: 113-114).

Art can be understood as an integral need of human beings along with various other purposes which cannot be set aside. The historical record informing its form in the earliest period is raised because it deals with the solemnity of rituals. The position of the historical record serves as a means of legality or ratification of a ritual, or even upheld as a ritual itself. The nature of being sacred, magical,and collective is inherent like a myth which almost always colors it. Through its simple categorized form, art offers a variety of wisdom.

The heritage findings are statues used as a means of honoring and personifying ancestors, tables or altars to offer offerings, vessels used for the offering container, sarcophagus or tomb of an important person, jewelry made from a series of beads, and animal bones, and others. The various spells are forms of abandoned recitation from the same period. Spells are used in rituals which are believed to be the means of a person avoiding a catastrophe with the title ruwat, ngaruat, lukat, or rokat. Nowadays poetry verses are often unrecognized literally, even by the culprits themselves. However, it does not diminish the charge of intrinsic values sought for its sustainability.

If the physical forms as data of art relics from prehistoric times can still be recognized even if not completely intact, different things happen in the performing arts data. The power of performing art survives very short, i.e. at the time of performances only. Moreover the recording media to make the performance art durable was not possible in its time. Unlike the case with art that has a solid nature and a longer life. Reliability assumptions and theories tend to emerge when digging and then building and organizing historical facts. The function of performing arts is aligned with the function of art objects left behind from the same period of time to obtain a picture of its construction.

After the prehistoric period, the emergence of the kingdoms marked the period of history. The kingdom left data to be read as evidence and historical facts. Kingdom was the center of birth, growth, and development of art. Its uniqueness and beauty were carried

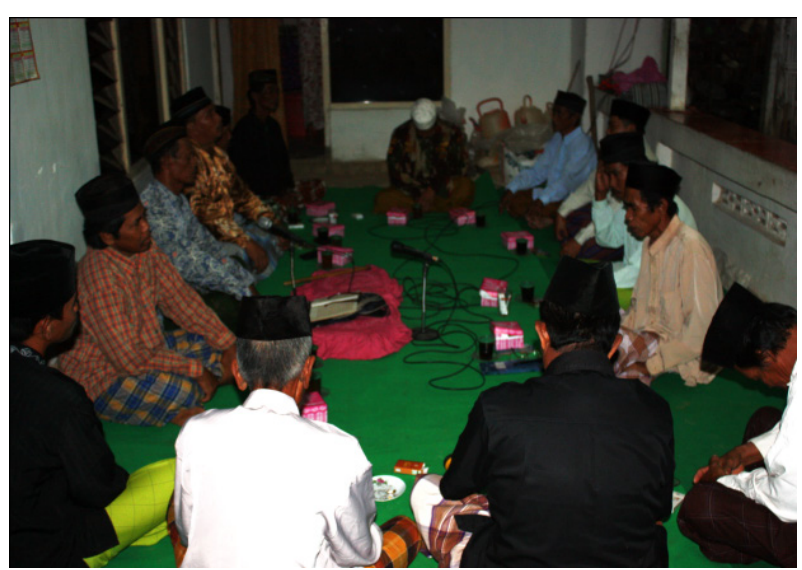

Figure 1. Other forms of cultural diversity are displayed through the wisdom of Mamaca which is played by 'Rukun Sampurna' group from Pameksan Sub-district of Pamekasan Madura Regency. (Documentation: Y. Adityanto Aji, 2009) 
as regalia by kings for the benefit of their respective kingdoms. Not a single kingdom in the archipelago did not preserve and place the arts as the completeness which was expected to uphold their greatness and dignity. This period was seen as part of the heyday of the development of art.

In its time, the implementation of sacred rituals with profane interests could go hand in hand. Two unequal interests were represented in one form. Its position as the completeness of rituals which was upheld and believed to have magical powers which coincided with its role as an art display which could provide pleasure. The doer watched or enjoyed ritual objects as works of art used in his activities.

The life cycle of humans with stages of the movement phase of their life especially the series of marriage events is one opportunity which is often used for various works of art. In addition, the votive vows which are held after the achievement of a hope are important events incorporating them in. Parts of the inclusion of these elements, its symbolic and meaningful embodiments must be raised on the occasion. The artwork presented at that time is better understood as a complement to the events of tradition, although it actually holds a certain meaning for the important events which are being carried out. Sacred as well as profane rituals take place among kings and nobles in palaces and common society outside the circle.

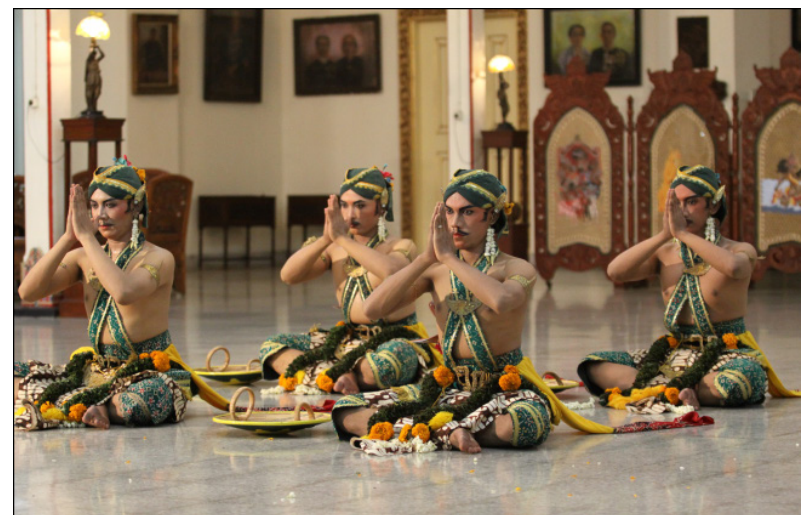

Figure 2. Beksan Bandabaya created by Sri Paku Alam II (ruled in 1829-1858). Its presence until now is a cultural preservation which requires the sincerity and perseverance of present and future generations as the heirs to continue.

(Pura Pakualaman Documentation, 2014)
In its time art and art of contemporary performances also evolved with various streams or types. In various manifestations, it was not uncommon to be entrusted with various wishes and expectations of stakeholders, such as being media of religious propaganda, political propaganda, social criticism, advertising, physical therapy, and even psychic.

Its development also aims to meet the curiosity of tourists. Not a few forms of art transform and adapt for the interest. R.M. Soedarsono, one of the experts and researchers of performing arts, discusses and formulates the characteristics of art which is packed for tourists. His rationale refers to pseudo traditional arts as proposed by J. Maquet which allows the occurrence of intersections of interest, namely: between aesthetic and economic interests(Pramutomo, Murtana, and Soemaryatmi, 2013: 258-259).

To meet market demand, some artists cannot avoid the mass production of art objects. For that purpose, sometimes the art is also used as a marketing medium. Economic factors become the determinant variables. Not a few support the way to earn a living through the art industry, although they often impact on the diminution of quality standards. Conversely, not a few parties oppose it. On events and occasions, various artistic representations are displayed together with various interests which are united in form. In this case, a wide variety of art forms can be watched and enjoyed by its beauty and uniqueness. Various media are used to express the intellectual and emotional awareness of each creator artists. It builds the awareness that Indonesia has a wide range of artworks. However, perhaps not all parties realize the importance of having a tangible or intangible art heritage which is infinite value. Efforts to nurture and strengthen diversity with certain values which it bears is often missed.

\section{Various Culture}

Multiculturalism owned by Indonesian nation is an accumulation of cultural mani- 
festations which have passed through space and time span of travel for centuries and supported by various determinants. Among the factors which helped determine that are more than three hundred tribes spread in the archipelago with a population close to $260,000,000$ inhabitants. The next factor is about 1,211 local languages in Indonesia (746 of which are used as spoken medium, both oral and written). The language speakers reside on a number of Indonesian islands totaling about 1,340 from all over the islands of more than 6,000 stretched from Sabang on the western side to Merauke on the east side (BPS, 2010).

The diversity of tribes and languages used as communicating instruments is followed by a diversity of knowledge, community, technology, livelihood, religion, and arts system which are upheld and organized. Thus, it can be known the owned wealthy and cultural diversity by various forms of art as parts of it.

In the vastness of a very open global era, as intercultural interactions intensify, a strong and resilient culture is needed. Timbul Haryono noted that in fact the wealth of the Indonesian nation in the form of diversity of cultural works represents a soft power to address the competition and the magnitude of influence in the era of openness. However, sooner or later, the safety and sustainability

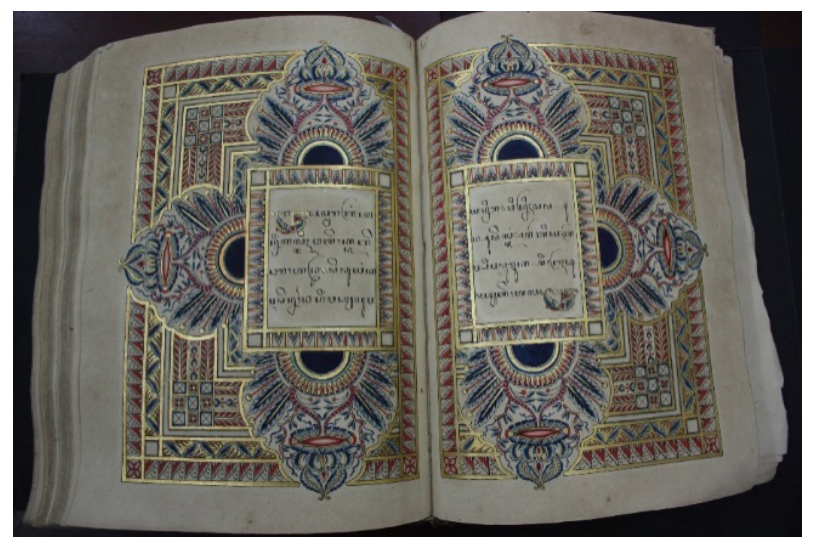

Figure 3. Various ways of maintaining and continuing the tradition strived by the predecessors wisely, among them are in the forms and contents of the 19th century manuscript entitled Sestradisuhul from the library of Paku Pakualaman palace. The manuscript includes life lesson through stories.

(Documentation: Y. Adityanto Aji, 2017) of diverse cultural riches can be threatened if they are not addressed by strengthening their sustainability. It is a matter of concern that some events which threaten the safety and preservation of cultural heritage including art as essential components are done by the community itself who should have nurtured and grown it. Nevertheless, with limitations, some forces continue to grow from the creativity and will of artists and their upright supportive community as a supporter of its continuity (Haryono, 2009: 2-3).

The diversity of wealth which has lasted for centuries needs to be strengthened by its sustainability. As something inherited, the continuation of the future is in the hands of the generation of the society in the present and future. The present and future generations uphold the great and heavy but noble responsibilities for saving diverse richness in order to achieve the welfare and salvation of the nation. Responsibility regarding education always implies liability (Lickona, 2013: 55, and 61 - 66). Thus, the community's responsibility for art sustainability is not limited to its participation, but rather mandatory. This compulsory participation in preservation activities must be strengthened through educational process.

In line with Timbul Haryono's ideas, Sri Sultan Hamengkubuwono X emphasizes that

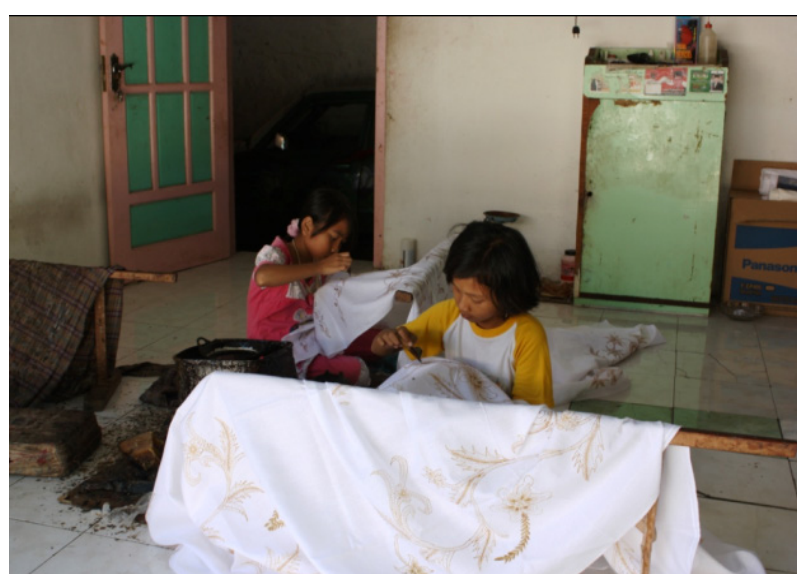

Figure 4. The two girls are responsible to strengthen and continue the tradition of beautiful batik. Year 2009 batik is included by UNESCO in the list of The Intangible Heritage of Humanity or culture of nonobject of human inheritance.

(Documentation: Y. Adityanto Aji, 2017) 
the defense of art is determined by the strength of its holder, as well as its development. Preservative power for self-preservation and as well as the progressive power for self-development are actually owned by art supported by the society. The toughness or vulnerability of art endurance depends on the awareness of its own supporters. The weaker the resilience of society, the stronger the penetration power of foreign [art] cultures towards it. If the opposite happens, the creativity of the community will find a way for its growth and development (Hamengku Buwono X, 2011: 7-8).

The community's pride in the art that is owned and supported needs to be continuously nurtured and cared for. Formal and nonformal education are places of nurturing and strengthening. The earlier the learning is given, the deeper and stronger the results can be achieved. The Minister of Education and Culture of the Republic of Indonesia for the period of 2009 - 2014 outlines that since elementary school education, children are accustomed to living together in diversity.

Concerning to education, a prominent figure and educational expert, H.A.R. Tilaar, puts forward the concept of art-culture education which has four distinctive features. Each of them is multilingual, multidimensional, multicultural, and multiintellegence.

1. Multilingual suggests that learners are expected to express themselves creatively through a variety of 'languages', including fine language, voice language, motion language, role language, and possible merging.

2. Multidimensional emphasizes the development of learners' competence in various concepts of art which combine aspects of aesthetics, logics, and ethics.

3. Multiculture grow and develop understanding and awareness of learners towards cultural diversity in the world and ability to appreciate it.

4. Multi intelligence concerns with the learners' intelligence which are expected to be achieved by studying more than one field, especially the field of art. This ability is intended to underlie and reinforce a harmonious personal building (Tilaar, 2004).

Opportunities of today and future young generation to get the opportunity to study with these four traits are necessary for selfdevelopment in accordance with the ability of each learner. Formal and non-formal education are desirable as places for its implementation.

Preserving as well as strengthening the sustainability of cultural wealth and its components must be comprehensive and holistic. It is necessary to consider the involvement of many stakeholders in coordination and in accordance with their respective areas of expertise and competence. Education is not only aimed at assisting the present and future generations in appreciating the achievements of the predecessors but is also intended to invite and demonstrate how to actively strengthen the defense of cultural heritage with art in it, both material and nonmaterial ones. (Haryono, 2019: 13-15).

Strengthening the sustainability of art requires proper handling, especially with its diversity. It takes tolerance and peace to maintain and affirm the diversity of art possessed. The public can not turn a blind eye to the occasional behavior of citizens who show less friendly attitude and stay away from tolerant. Community figures through screen media, print media, social media and virtual worlds call for mutual tolerance. Again and again the government, in this case President Joko Widodo, directly reminds and affirms that the public must realize that Indonesia is multicultural. Multiculture is the advantage of the Indonesian nation which is not owned by other nations. These differences, however, are united by an unchallenged power of nationalism. One of the speeches of President Joko Widodo put forward a metaphor stating that in the blood of the Indonesian nation flows the same Deoxyribo Nucleic Acid (DNA), that is art - culture. If within the diversity there is also a 'cell nucleus' similarity system, these similarities can not be mutually exclusive and can not be questioned. Society must actually strengthens the similarity together 
by prioritizing tolerance so that its diversity can continue and become a common pride.

Indonesian artistic-culture life is very diverse but it continues to seek tolerance and peace to the attention of various parties including the 44th president of the United States, Barack Obama. Toward the end of his visit to Indonesia, in a speech in Jakarta he conveyed his support for cultural diversity in Indonesia. Such support is called, as well as inviting other countries, to imitate the diversity that goes in tolerance like Indonesia. Tolerance is a necessary way now to soothe an atmosphere that is not conducive due to various causes.

The role of art colleges, such as the Indonesian Art Institute of Yogyakarta, is highly anticipated to contribute to the peaceful atmosphere. The learning process that places the local arts as the object of the material becomes one of the efforts to recognize and understand the diversity of culture. The introduction and understanding of this material object is not only of a particular facet, but is comprehensive. The preparation of lecturers with the appropriate competence and unquestioned capacity ability is an institution's step to be consistent and responsible for its role as an art college serving not only as the oldest in its age but also striving to continue to be the leader in Indonesia.

The government has been taking concrete steps to encourage the strengthening of

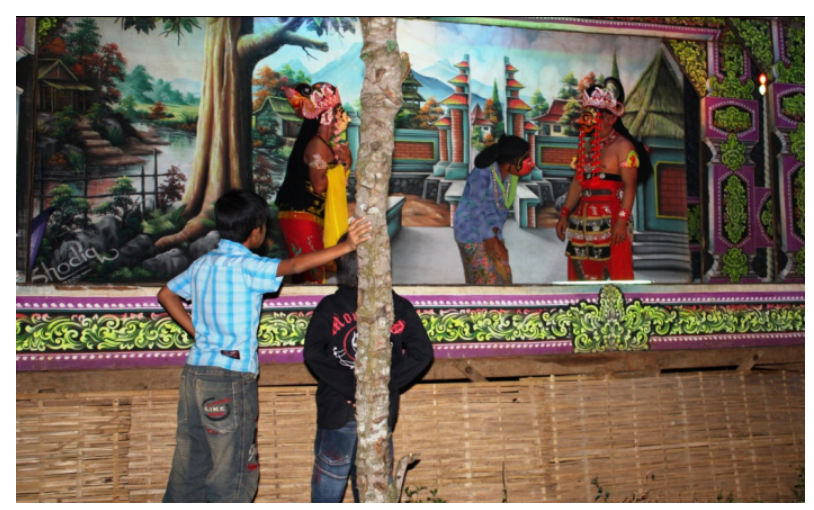

Figure 5. The sustainability of the performing arts lies in the hands of current and future generations, including two children who participated in the performance of Topeng Dhalang 'Rukun Perawas' in Kecamatan Dasuk, Kabupaten Sumenep Madura.

(Documentation: Y. Adityanto Aji, 2017) multiculturalism in peaceful and beautiful tolerance. The $72^{\text {nd }}$ anniversary of Indonesia's Independence Day on August 17, 2017 was colored by the festivities of various traditional clothing. President Joko Widodo and Mrs. Iriana Joko Widodo along with Vice President Jusuf Kalla and Mrs. Mufidah Jusuf Kalla together with all ministers, presidential staff, and guests wore traditional clothing from various regions of the archipelago. This is an important milestone for affirmation of togetherness in differences.

\section{Conclusion}

The uniqueness of art arises from the characteristics of each aspect of its constituent. There is no doubt that Indonesia is a country rich in art diversity. Its diversity is sustained by facts, both physical and non-physical ones. The existence of hundreds of tribes with the language used, followed by various components that show the cultural diversity with the art inherent in it.

Artcontinues to grow together and support the interests of human beings, individually and collectively, from time to time. Its form is very plural shown to be enjoyed as a work having main aesthetic values. Various art exhibitions, recitals and orchestra, performances of wayang kulit, theater performances, choreography presentations, etc. are seriously processed and then displayed in the achievement of aesthetic qualities according to the ideas of artists.

A number of plural forms of art and that characterize a variety of uniqueness and beauty is really grateful for its existence. Plurality, uniqueness, and beauty presented by the senses of the artists of stakeholders is none other than to put forward the main purpose. The journey of experience through a deep impression as the basis of the artist's intelligence becomes a tremendous power when it proceeds to create and present it. Various art coming through the struggle against the forces of nature, space, and time which is not always friendly creates a creativity that manifests from the depth of feeling and clarity and intelligence thinking. 


\section{References}

BPS. 2010. Jakarta: Badan Pusat Statistik Republik Indonesia.

Buwono X, Hamengku. 2011. Ajaran Sang Amurwabumi: Sumber Acuan Nilai-Nilai Pendidikan Karakter Bangsa, Pidato Penganugerahan Gelar Doctor Honoris Causa Bidang Seni Pertunjukan Institut Seni Indonesia Yogyakarta.

Dewantara, Ki Hadjar. 1976. Bagian II A: Kebudajaan, Yogyakarta: Majelis Luhur Persatuan Taman Siswa.

Haryono, Timbul. 2000. Peran Masyarakat Intelektual dalam Pelestarian Warisan Budaya Lokal, Pidato Ilmiah pada Dies Natalis ke-63 Fakultas Ilmu Budaya Universitas Gadjah Mada.

Junaedi, Deni. 2016. Estetika Jalinan Subjek, Objek, dan Nilai. Yogyakarta: ArtCiv.

Kusmayati, A.M. Hermien. 2013. "Performing Arts as Cultural Identity" keynote speaker dalam The $1^{\text {st }}$ International Conference on Performing Arts.

Kusmayati, A.M. Hermien. 2006. "Aspek Etika dalam Bingkai Seni Pertunjukan" Pidato Pengukuhan Jabatan Guru Besar pada
Fakultas Seni Pertunjukan Institut Seni Indonesia Yogyakarta.

Lickona, Thomas. 2013. Pendidikan Karakter: Panduan Lengkap Mendidik Siswa Menjadi Pintar dan Baik. Bandung: Nusa Media.

Marianto, M. Dwi. 2017. Art \& Life Force in a Quantum Perspective. Yogyakarta: Scritto Book Publisher.

Pramutomo, R.M., I Nyoman Murtana, dan Soemaryatmi. 2013. "Perancangan Desain Pengalaman Turistik melalui Ecotourism Rumah Adat Bali Kuno di Desa Mangesta Kecamatan Penebel Kabupaten Tabanan Propinsi Bali" dalam Kawistara, vol. 3, No. 3, $252-262$.

Soedarsono, R.M., 2010. Seni Pertunjukan Indonesia di Era Globalisasi. Yogyakarta: Gadja Mada University Press.

Sumardjo, Jakob. 2006. Estetika Paradoks. Bandung: Sunan Ambu Press.

Sutrisno, Mudji. 2010. Ranah-Ranah Estetika. Yogyakarta: Kanisius.

Tilaar, H.A.R., 2004. "Multikulturalisme Tantangan-Tantangan Global Masa Depan" dalam Transformasi Pendidikan Nasional. Jakarta: Gramedia Widiasarana Indonesia. 